\title{
Population Group
}

National Cancer Institute

\section{Source}

National Cancer Institute. Population Group. NCI Thesaurus. Code C17005.

A group of individuals united by a common factor (e.g., geographic location, ethnicity, disease, age, gender) 